\title{
Chapter 3 \\ Landscape Response to Climate and Human Impact in Western China During the Han Dynasty
}

\author{
Steffen Mischke, Chengjun Zhang, Chenglin Liu, Jiafu Zhang, \\ Zhongping Lai and Hao Long
}

\begin{abstract}
The Chinese empire experienced a large expansion to the arid regions in the west during the Han Dynasty (206 BCE-220 CE). The Hexi Corridor, the Yanqi Basin, the southeastern part of the Junggar Basin and the Tarim Basin became part of the empire. The expansion of the Han Dynasty was accompanied by the significant intensification of irrigation farming along rivers draining the Qilian, Tianshan and Kunlun Mountains. Sedimentological and geochemical analyses and dating of lake sediments and shorelines revealed that four large lakes in the region experienced falling levels, or were almost or completely desiccating. The level of Zhuyeze Lake was falling rapidly ca. 2100 years before present (a BP), and the accumulation of lake sediments was replaced by an alluvial fan setting in large parts of the basin. Lake Eastern Juyan desiccated ca. 1700 a BP. Lake Bosten experienced low levels and increasing salinities at ca. 2200 a BP. Lake sediments in the Lop Nur region were mostly replaced by aeolian sands during a period of near-desiccation at 1800 a BP. In contrast, records from fifteen lakes farther in the west, north or south of the Han Dynasty realm indicate relatively wet climate conditions ca. 2000 years ago. Thus, dramatic landscape changes including the near and complete desiccation of large
\end{abstract}

\author{
S. Mischke $(\square)$ \\ Faculty of Earth Sciences, University of Iceland, 101 Reykjavík, Iceland \\ e-mail: smi@hi.is \\ C. Zhang
}

School of Earth Sciences and Key Laboratory of Mineral Resources in Western China, Lanzhou University, Lanzhou 730000, China

C. Liu

Institute of Mineral Resources, Chinese Academy of Geological Sciences, Beijing 100037, China

J. Zhang

MOE Laboratory for Earth Surface Processes, Department of Geography, College of Urban and Environmental Sciences, Peking University, Beijing 100871, China

Z. Lai

Institute of Marine Science, Shantou University, Shantou 515063, China

H. Long

Nanjing Institute of Geography and Limnology, Chinese Academy of Sciences (NIGLAS), Nanjing 210008, China

(C) The Author(s) 2019

L. E. Yang et al. (eds.), Socio-Environmental Dynamics along the Historical Silk Road, https://doi.org/10.1007/978-3-030-00728-7_3 
lakes in the arid western part of today's China probably resulted from the withdrawal of water from tributaries during the Han Dynasty. These changes likely represent the earliest man-made environmental disasters comparable to the recent Aral-Sea crisis.

Keywords Central Asia $\cdot$ Xinjiang $\cdot$ Inner Mongolia $\cdot$ Gobi Desert

Lake desiccation

\subsection{Introduction}

The climate conditions in the Chinese section of the ancient Silk Road during the Han Dynasty have not been addressed by many studies so far. Climate change research usually focussed on longer time scales such as the Holocene, or on recent global change (Liu et al. 2008, 2015a; Tao et al. 2010; Yang and Liu 2014). The work on Holocene climate records is often motivated by the need to understand climatecontrolled environmental change since the last ice age with special emphasis on the rapidness and amplitude of environmental change during times of natural climate changes without human impact but with comparable climatic controls of the Earth's orbital parameters (Wünnemann et al. 2012; Fan et al. 2014). As a result, periods of maximum moisture and temperature of northwestern China have been proposed in the early and middle Holocene (Liu et al. 2015a; Chen et al. 2016). However, the climate and environmental conditions in northwestern China specifically during the Han Dynasty deserve more attention of the palaeoclimate community because the Han Dynasty expansion of the Chinese empire had caused a large population migration towards the west accompanied by significant land use changes (Zhang et al. 2003, 2011; Yang et al. 2006; Lü et al. 2009; Qin et al. 2012). A recent study by Mischke et al. (2017) showed that water withdrawal from the tributaries of the large ancient Lake Lop Nur in the eastern Tarim Basin for irrigation farming caused not only the near-desiccation of the lake ca. 1800 years before present (a BP) but eventually also the abandonment of the Loulan Kingdom upstream of Lop Nur. Thus, human impacts on environments along the Silk Road apparently already reached a significant magnitude during or shortly after the Han Dynasty. We follow and extent the approach of Mischke et al. (2017) here by assessing and comparing the available palaeoenvironment and palaeoclimate records from northwestern China and surrounding regions with special emphasis on the Han Dynasty period. Which environmental and climate conditions can be inferred for northwestern China and surrounding regions during the Han Dynasty? Are there spatial differences in environmental and climate conditions, and if so, can these differences be linked to changes in westerlies or summer monsoon precipitation? Alternatively, were spatial differences in environmental conditions possibly caused by man? 


\subsection{Previous Research}

The Holocene climate history of northwestern China and surrounding regions was addressed by relatively many studies in the last decades. Studies often focussed on the Holocene "Climatic Optimum" in China, i.e. the identification of the warmest and wettest period of the Holocene (Zheng et al. 1998; An et al. 2000; Chen et al. 2008). Ca $2-4{ }^{\circ} \mathrm{C}$ warmer conditions synchronously in different regions of China between 9000 and 6000 a BP were postulated by Zheng et al. (1998). In contrast, An et al. (2000) suggested that warmest and wettest conditions culminated at 11,000, between 10,000 and 8000 or 10,000 and 7000 , between 7000 and 5000, or at 3000 a $\mathrm{BP}$ in different regions of China. Highest lake levels along the eastern section of the Silk Road in the Hexi Corridor region occurred mostly between 10,000 and 7000 a BP. Chen et al. (2008) and Wang et al. (2010) argued that the arid regions of Central Asia or the area influenced mainly by the East Asian Summer Monsoon experienced wettest conditions during the middle Holocene whilst the more humid part influenced by the Indian Summer Monsoon received higher precipitation in the early Holocene. Relatively dry conditions during the early Holocene were also reported for locations along the ancient Silk Road in Xinjiang (Bosten Lake, Aibi Lake, Wulungu Lake, Balikun Lake) or further to the east in the Hexi Corridor of Gansu (Lake Zhuyeze; Liu et al. 2008; Tao et al. 2010; Zhang et al. 2010; Wang et al. 2013; Mischke et al. 2016). The Han Dynasty climate was not specifically addressed in these studies. However, the lake records from Aibi, Wulungu and Balikun suggest relatively wet conditions ca. 2000 a BP whilst Lake Bosten and Lake Zhuyeze experienced falling lake levels.

In contrast to studies of the Holocene climate conditions in northwestern China and surrounding areas in general, archaeological investigations of Han Dynasty sites in northwestern China included discussions of the specific climate conditions as potential drivers of oases evolution and abandonment during and after the Han Dynasty. For example, Qin et al. (2012) described that the Loulan Kingdom and intensive farming in the eastern Tarim Basin was established during a climatically favourable wet period between 2100 and 1700 a BP and that its abandonment was apparently a result of climatic aridification of the region afterwards. Similarly, the oasis Yuansha in the Keriya River region at the southern margin of the Tarim Basin was thriving during relatively wet climate conditions before 2200 a BP and eventually abandoned 1600 a BP following a first avulsion of the Keriya River at 2200 a BP and a drought at ca. 1900 a BP (Zhang et al. 2011). Zhou et al. (1994) also discussed the natural diversion of rivers, drier climate and social unrest as possible causes that may have led to the decline of oases in the Keriya River region. Zhang et al. (2003) described that warm and wet climate conditions between 2800 and 1900 a BP led to significantly larger water resources in the Tarim Basin and flourishing desert oases which were abandoned due to deteriorating climate after 1800 a BP. Yang et al. (2006) reconstructed the extent of irrigated farmlands in the Tarim and Yanqi Basin (including Bosten Lake) during the Han Dynasty. They concluded that irrigation farming was widespread between 2200 and 1500 a BP and that changing climate probably 
caused the termination of the oases in the Tarim Basin. Thus, climate deterioration was mostly assumed as the main cause of the decline of local kingdoms and desert oases along the ancient Silk Road between 1900 and 1500 a BP.

\subsection{Discussion of Climate Records from Northwestern China and Surrounding Regions}

\subsubsection{Lake Records from the West}

Three lake records were analyzed from the Pamir Mountains in the westernmost part of the discussed region: records from Sasikul, Karakul and Karakuli lakes (Figs. 3.1, 3.2, Table 3.1). The records were obtained from alpine lakes at more than $3600 \mathrm{~m}$ above sea level (asl) representing relatively small catchment areas. The $\delta^{18} \mathrm{O}$ values of fine-grained carbonate from Sasikul Lake are generally high during the Han Dynasty period but also high during the 300 a before (since the start of the record) and in the following centuries (Lei et al. 2014). Consequently, relatively dry conditions are inferred from the high $\delta^{18} \mathrm{O}$ values of the closed-basin lake. Relatively comparable $\delta^{18} \mathrm{O}$ values of fine-grained carbonate were provided for the closed basin of Lake Karakul $150 \mathrm{~km}$ north of Sasikul Lake. Here, $\delta^{18} \mathrm{O}$ values are highest during the middle of the Han Dynasty but decreasing towards the end of the Han and later on too (Mischke et al. 2010; Fig. 3.2). Increasingly wet conditions existed at Lake Karakul during the Han Dynasty and in the subsequent centuries. The study of Aichner et al. (2015) applied compound-specific stable isotope analysis to the sediments of Karakuli Lake which is $150 \mathrm{~km}$ to the southeast of Karakul Lake. The $\delta \mathrm{D}$ values for terrestrial biomarkers decrease throughout the Han Dynasty and remain low in the centuries afterwards, and increasingly wet conditions during the Han are inferred from Karakuli Lake too (Fig. 3.2).

Two lake records are available from the central Tianshan Mountains in the northeast of the Pamirs (Fig. 3.1). Son Kol Lake is an open-basin lake at $3016 \mathrm{~m}$ asl and Issyk-Kul is a closed basin lake at $1607 \mathrm{~m}$ asl. The catchment areas of both lakes are relatively small in comparison to the lake surface areas, representing relatively local conditions similar to the Pamir lakes (Savvaitova and Petr 1992). Lauterbach et al. (2014) used $\delta^{15} \mathrm{~N}$ values of organic matter in lake sediments as proxy for winter snowfall in the Son Kol Lake catchment. Increasing winter precipitation during and after the Han Dynasty is inferred from the $\delta^{15} \mathrm{~N}$ increase (Fig. 3.2). The low $\delta \mathrm{D}$ values for a terrestrial biomarker $\left(\delta \mathrm{D}_{n-\mathrm{C} 29}\right)$ during the Han Dynasty suggest wet climate conditions whilst decreasing $\delta \mathrm{D}$ values in the following centuries indicate diminishing summer precipitation. However, high winter precipitation during the centuries following the Han Dynasty probably maintained generally wet climate conditions in the region. Stable oxygen isotope values for ostracod (micro-crustacean) shells from Issyk-Kul Lake were highest before the beginning of the Han Dynasty and slightly lower afterwards (Ricketts et al. 2001; Fig. 3.2). The timing of the $\delta^{18} \mathrm{O}$ 
3 Landscape Response to Climate and Human Impact in Western China ...

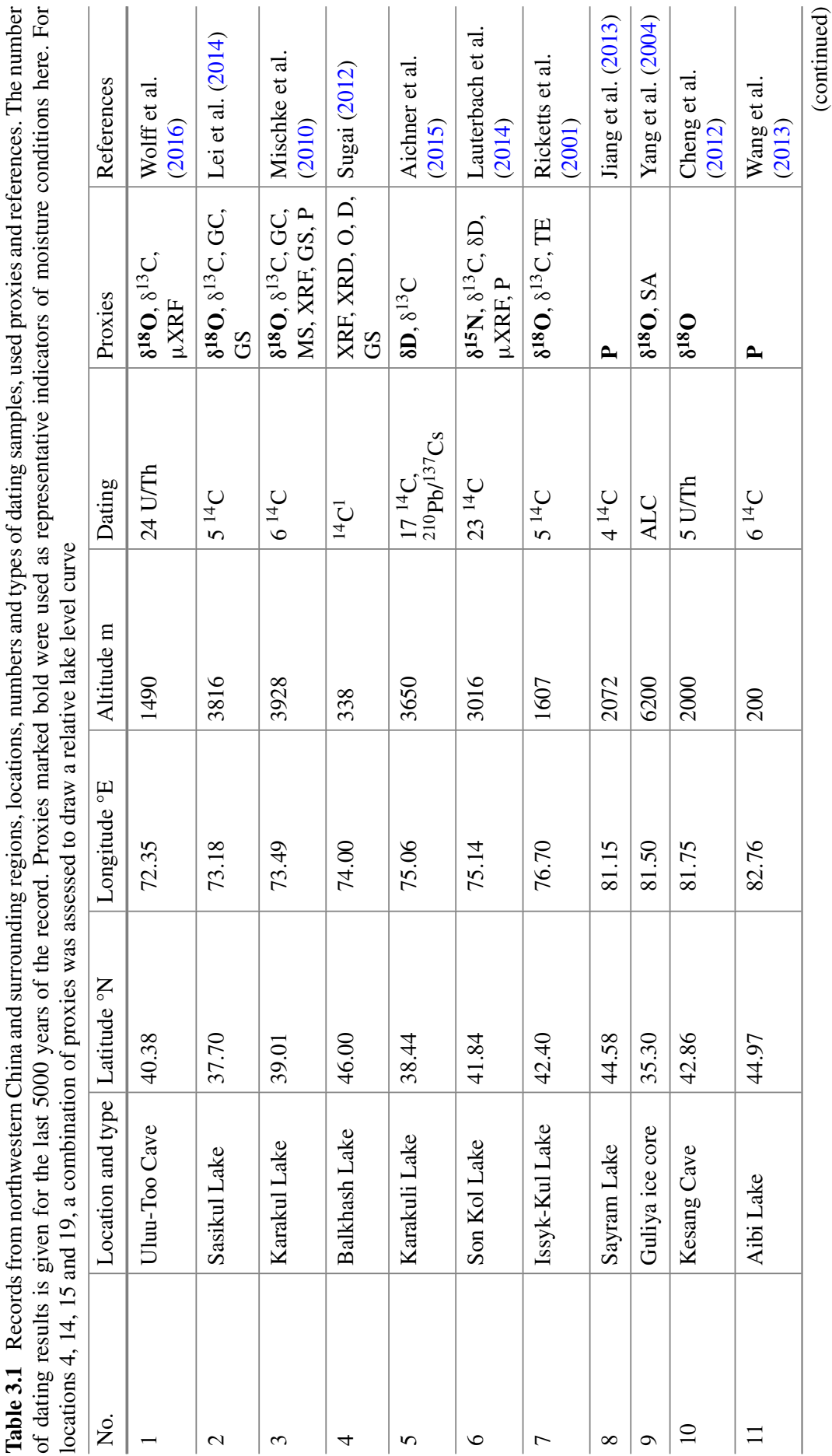




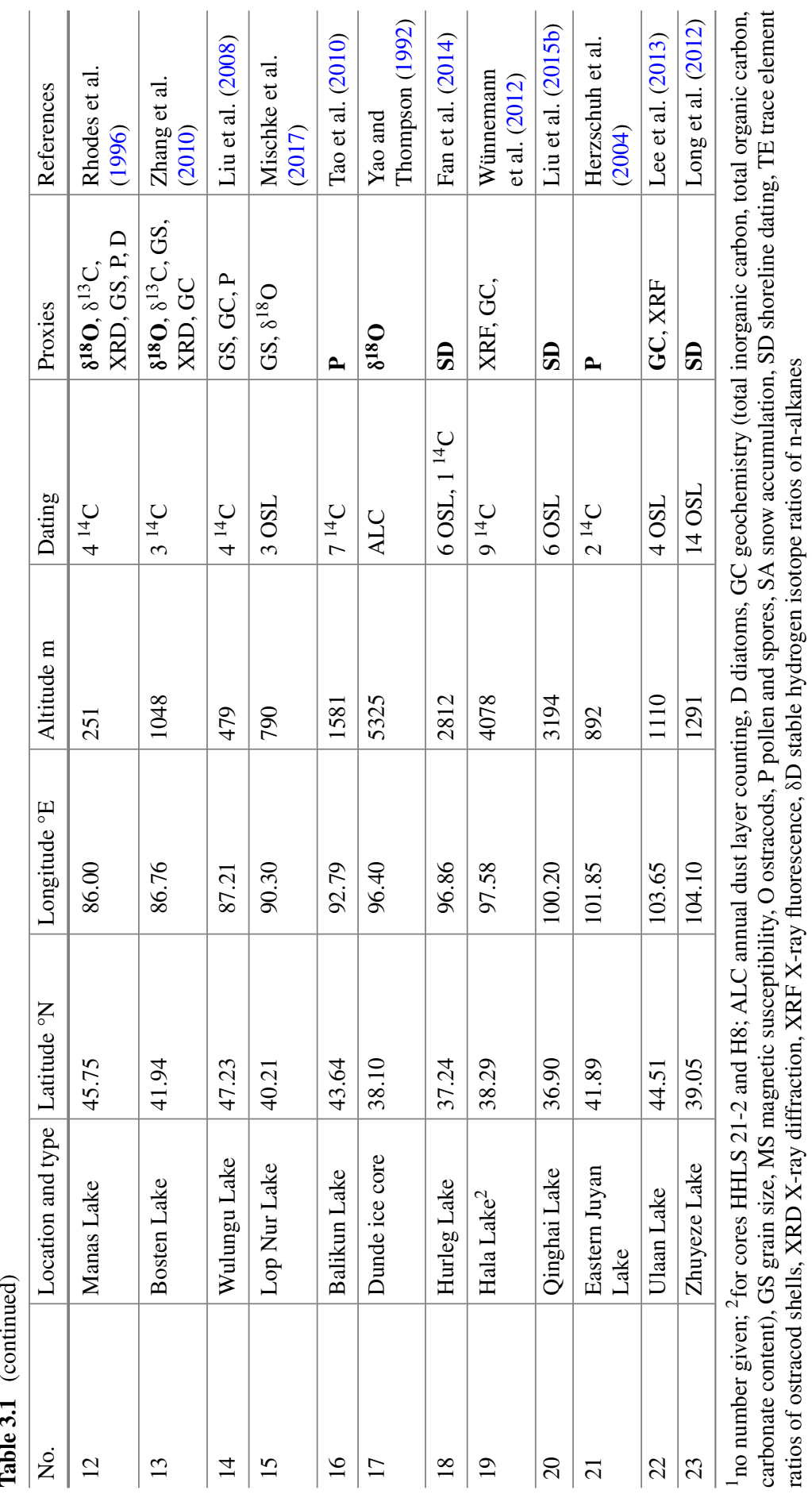




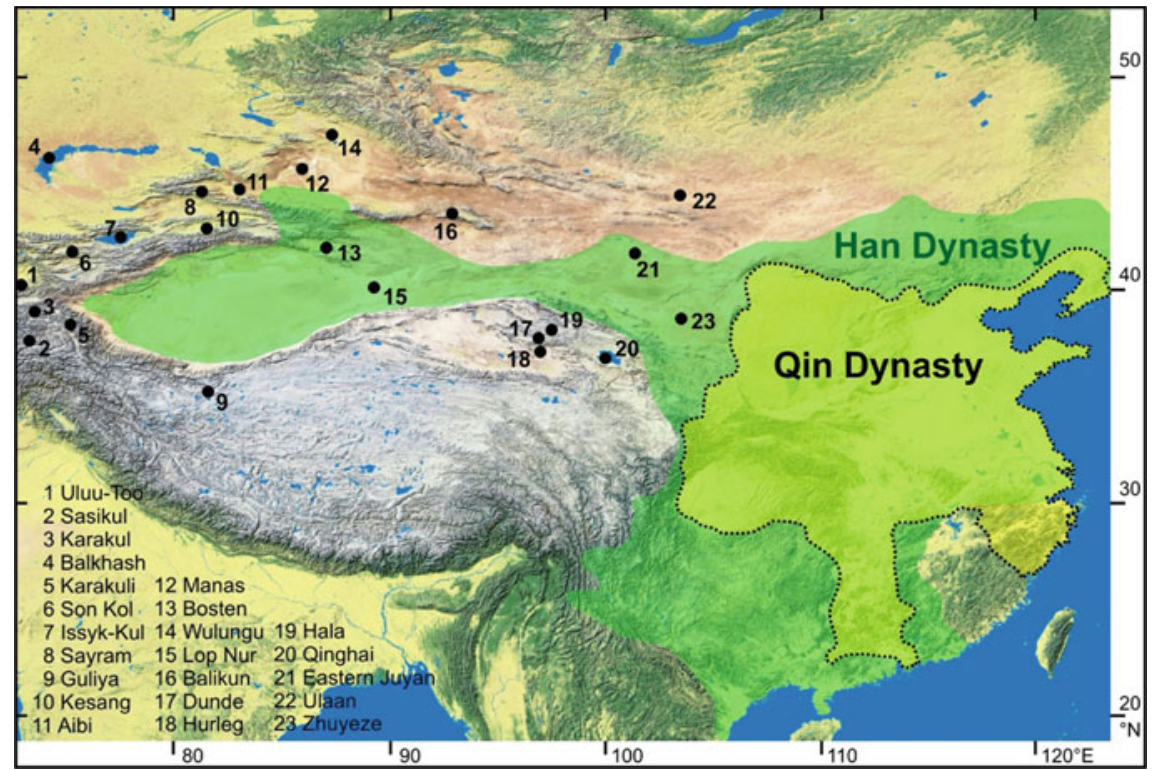

Fig. 3.1 Location of the reviewed climate records from northwestern China and surrounding regions. Extent of Qin Dynasty (light green and dotted line) and of Han Dynasty (green) empires marked. (References provided in Table 3.1)

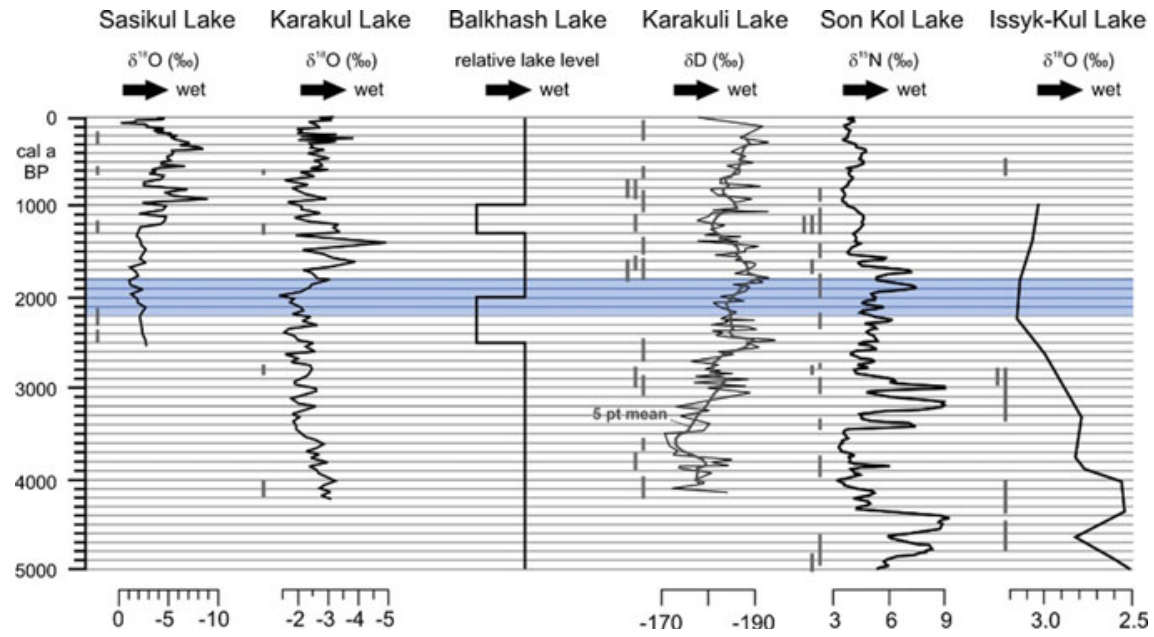

Fig. 3.2 Lake records from the western section of the discussed region. Vertical grey bars at left of records indicate calibrated ${ }^{14} \mathrm{C}$ ages with $2 \sigma$ error ranges. Duration of Han Dynasty marked by blue bar. (References and additional chronological information provided in Table 3.1)

record is not well constrained for the period of the Han Dynasty due to the absence of radiocarbon data between about 3000 and 500 a BP but relatively low changes of 
the sediment accumulation rate might be expected for a large and deep lake such as Issyk-Kul (Fig. 3.2). Interpolated sample ages between dated stratigraphic levels in the obtained sediment core are probably relatively robust. However, the decrease of $\delta^{18} \mathrm{O}$ values over the Han period probably represents a rising lake level which led to overflow conditions and a lake level at least $16 \mathrm{~m}$ higher than present between 1400 and 1200 a BP. Thus, increasingly wet conditions were inferred from the lakes Son Kol and Issyk-Kul in the central Tianshan Mountains.

Balkhash Lake in the northern foreland of the Tianshan Mountains lies at ca. $340 \mathrm{~m}$ asl. The closed-basin lake drains a large catchment area of 501,000 $\mathrm{km}^{2}$ including the northern ranges of the Tianshan Mountains and the Dzungarian Alatau (Chiba et al. 2016). Palaeoclimate signals from the lake are therefore expected to integrate local peculiarities and should represent regional climate conditions. However, late Holocene climate records from the lake presented in previous years often cover only the last 1000 or 1800 a BP and do not include the period of the Han Dynasty (Endo et al. 2010; Narama et al. 2010; Chiba et al. 2016). The rough assessment of relative lake level changes of Sugai (2012) includes two periods of low lake levels between 2500 and 2000 a BP and 1300 and 1000 a BP (Fig. 3.2). Correspondingly, a lowlake-level period between 2500 and 1800 a BP was described by Akhmetyev et al. (2005). Relatively dry conditions existed in the catchment of Balkhash Lake during the early half of the Han period or the entire Han time, which subsequently gave way to wetter conditions in the region.

\subsubsection{Lake Records from the Central Region}

One additional lake record is available from relatively high altitude in the eastern Tianshan Mountains. Pollen data were reported from Sayram Lake which is surrounded by steppe vegetation (Jiang et al. 2013). The setting of the lake with relatively dense vegetation in its vicinity and its moderate size $\left(453 \mathrm{~km}^{2}\right)$ suggest that the pollen record mostly represents local and regional vegetation. Pollen transported over far distances contributed probably to a minor degree to the recorded assemblages. The Artemisia/Chenopodiaceae (A/C) ratio was used as a moisture indicator to discriminate between steppe (higher $\mathrm{A} / \mathrm{C}$ ratios) and desert (lower $\mathrm{A} / \mathrm{C}$ ratios) vegetation (Jiang et al. 2013). The A/C ratio is increasing continuously from ca. 2500 a BP to 800 a BP, and increasingly wetter conditions are inferred over the period of the Han Dynasty (Fig. 3.3).

Three lake records were presented for the Junggar Basin between the Tianshan Mountains in the south and the Altai Mountains in the north (Fig. 3.1). Aibi Lake is a closed-basin lake in the southwestern part of the Junggar Basin $150 \mathrm{~km}$ east of Sayram Lake. Pollen data from the desert environment of the lake probably represent regional vegetation changes. The pollen concentration as a measure of vegetation density and the $\mathrm{A} / \mathrm{C}$ ratio increase from 3600 to 1400 a BP (Wang et al. 2013). Increasing moisture availability is inferred for the Han Dynasty period in the Aibi Lake region (Fig. 3.3). Manas Lake $250 \mathrm{~km}$ further northeast of Aibi Lake was a terminal salt lake until the 
1960s before the lake turned into a salt-covered playa as a result of the diversion of the entering Manas River for agricultural purposes (Rhodes et al. 1996). Lake and river sediments were recovered in Holocene sediment cores from near the former lake's centre. Phases of lake formation regarded as wetter climate periods existed from 4500 to 2500 a BP and from 2000 to 1000 a BP. The $\delta^{18} \mathrm{O}$ values for carbonate increase during the initial period of lake formation after $2000 \mathrm{a}$ BP as a result of the evaporative enrichment in a stagnant water body. $\delta^{18} \mathrm{O}$ values from the river period before the lake phase are not regarded as good climate proxy here because they likely represent a mixed signal of detrital carbonate grains from Mesozoic limestones in the upper reaches of the Manas River, reworked carbonate from earlier deposited lake carbonates in Manas Lake, and possibly authigenic carbonate formed in the slowlyflowing river. However, a transition from drier to wetter conditions is reflected during the Han Dynasty through the replacement of river sediments by lake sediments at about 2000 a BP (Fig. 3.3). Wulungu Lake $180 \mathrm{~km}$ further northeast receives water from the southern slopes of the Altai Mountains. A multiproxy record of grain size, geochemistry and pollen data from the terminal lake was used by Liu et al. (2008) to construct a lake level curve for the Holocene. The surroundings of the lake are characterized by desert vegetation and the pollen record is regarded to reflect regional vegetation changes. The authors recorded a high lake level during the Han Dynasty and a change from desert steppe to steppe vegetation in the region (Fig. 3.3). Thus, relatively wet conditions were recorded for the northern part of the Junggar Basin.

A $\delta^{18} \mathrm{O}$ record of authigenic carbonate from Bosten Lake in the Yanqi Basin between the Junggar and Tarim basins was provided by Zhang et al. (2010). Although Konqi River is the outflow of Bosten Lake, the lake probably behaves like a semiclosed lake due to the close location of the in- and outflows at its western margin (Mischke and Wünnemann 2006). As a result, a significant W-E oriented salinity

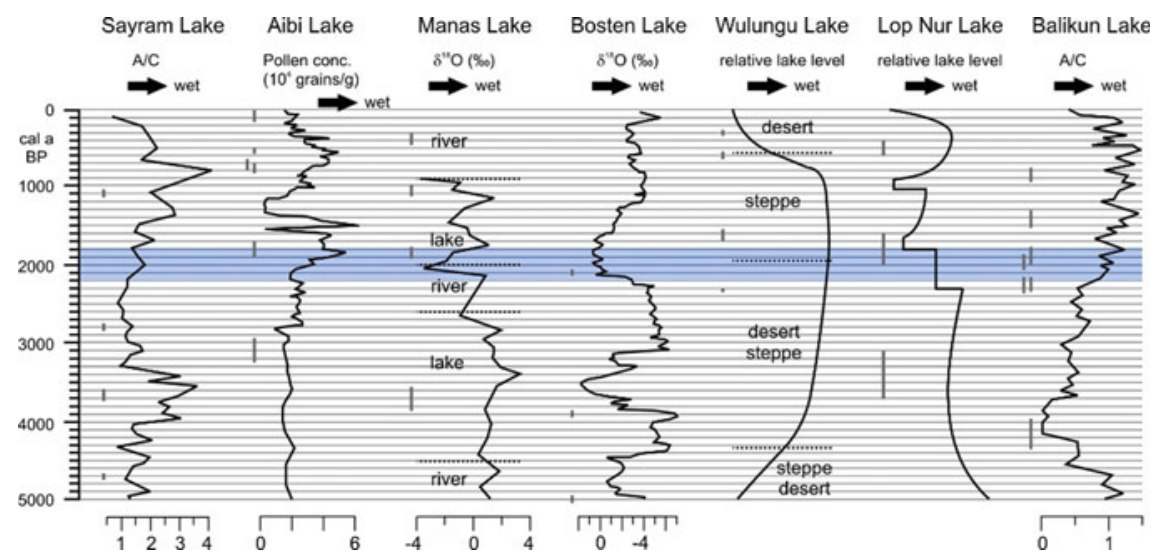

Fig. 3.3 Lake records from the central section of the discussed region. Vertical grey bars at left of records indicate age data with $2 \sigma$ error ranges. Duration of Han Dynasty marked by blue bar. (References and additional chronological information provided in Table 3.1) 
gradient from 0.5 to $2.5 \%$ exists in the lake (Jin et al. 1990). The $\delta^{18} \mathrm{O}$ values rapidly increase at the beginning of the Han Dynasty as a result of a reduced inflow in comparison to evaporation. The $\delta^{18} \mathrm{O}$ values remain high during the Han period and in the subsequent two centuries (Fig. 3.3). Rapidly decreasing moisture availability with a significantly reduced inflow to the lake in the early part of the Han Dynasty and dry conditions afterwards are suggested based on the Bosten Lake data.

Lop Nur Lake $350 \mathrm{~km}$ further to the southeast of Bosten Lake was a terminal lake before its desiccation in the late 1930s or early 1940s. The lake represented the base level for the Konqi and Tarim rivers. Stable isotope data of carbonate and grain-size data of detrital sediments from a dug section in the centre of the dry lake basin were discussed by Mischke et al. (2017) who argued that a first period of massive aeolian sand deposition in the lake basin occurred 1800 a BP and caused the near-desiccation of the lake. A relative lake level curve based on the earlier presented data includes two periods of rapid lake-level lowering before and at the end of the Han Dynasty (Fig. 3.3). Thus, diminishing moisture availability during the Han period is indicated by the record from Lop Nur.

Another mountain foreland lake record was provided from Balikun Lake some $430 \mathrm{~km}$ in the northeast of Lop Nur (Tao et al. 2010). The A/C ratios for a Holocene lake sediment core increase steadily over the Han Dynasty period with a minor drop recorded following the termination of the Han time (Fig. 3.3). However, A/C ratios increase from the middle Holocene at about 4000 a BP to the late Holocene at about 1000 a BP, and relatively wet conditions are inferred for the Han Dynasty period.

\subsubsection{Lake Records from the East}

A lake record from the large Qaidam Basin between the Qilian Mountains in the north and the Kunlun Mountains in the south, and two records from intramontane basins in the Qilian Mountains represent climate archives from relatively high altitude in the eastern part of the examined region. Hurleg Lake is an open-basin lake in the eastern Qaidam Basin with a moderate catchment area of 12,600 km ${ }^{2}$ (Fan et al. 2014). Shoreline deposits above the present lake level were dated using optically stimulated luminescence (OSL) dating and used as proxies of higher lake levels during wetter periods. The proposed high lake-level period between ca. 2200 and 1400 a BP suggests that the time of the Han Dynasty was a wetter period in comparison to today's conditions in the region (Fig. 3.4). Hala Lake $130 \mathrm{~km}$ to the northeast is a terminal lake which was studied as a climate archive in detail by Wünnemann et al. (2012). Their multi-proxy data were synthesized in a relative lake level curve (Fig. 3.4). Rising lake levels starting a few centuries before the beginning of the Han Dynasty and continuing a few centuries afterwards suggest increasingly wet conditions during the Han time. Qinghai Lake $270 \mathrm{~km}$ to the southeast of Hala Lake is also a closed-basin lake (Fig. 3.1). OSL dating of shoreline deposits suggests that relatively low levels existed before the Han Dynasty, rising levels during the period of the Han, and high levels at its end and in the subsequent centuries (Fig. 3.4; Liu 
et al. 2015b). Thus, relatively wet conditions are inferred from Qinghai Lake for the Han time too.

Two lake records were presented from the northern foreland of the Qilian Mountains. Eastern Juyan Lake was a terminal lake $600 \mathrm{~km}$ north of Qinghai Lake. The lake was fed by the Hei River which flows towards the northwest in the Hexi Corridor. The river formed one of the largest alluvial fans of the world covering an area of $30,000 \mathrm{~km}^{2}$ in the west of the Badain Jaran Sand Sea. An abrupt change from lake carbonates to sands in the top of an $8 \mathrm{~m}$ thick Holocene sediment sequence suggests the desiccation of the lake 1700 a BP (Herzschuh et al. 2004). The modern vegetation in the former lake region consists of semi-desert and desert plant communities, and the pollen record from the lake sediments is regarded to represent regional vegetation changes. Lowest precipitation in the region was reconstructed in the centuries preceding the Han Dynasty, and a slight increase in moisture availability was recorded during the Han time (Fig. 3.4). However, the rapid onset of dry conditions is implied by the desiccation of the lake $1700 \mathrm{a}$ BP. The second lake record from the Qilian Mountains foreland originates from Zhuyeze Lake $380 \mathrm{~km}$ to the southeast of Eastern Juyan Lake. The lake is the terminal lake of the Shiyang River which drains the northeastern part of the Qilian Mountains and the eastern section of the Hexi Corridor. Most of the lake basin is dry today due to water withdrawal from Shiyang River for irrigation farming upstream. The remaining Baijian Lake is a salt swamp in the eastern part of the former lake basin. Dating of shoreline and lake deposits was conducted by Long et al. (2012) who draw a relative lake-level curve for the Holocene history of the basin. Continuously decreasing lake levels since the middle Holocene were reconstructed (Fig. 3.4). Higher levels before the Han Dynasty and lower levels afterwards suggest that relatively dry conditions prevailed during the

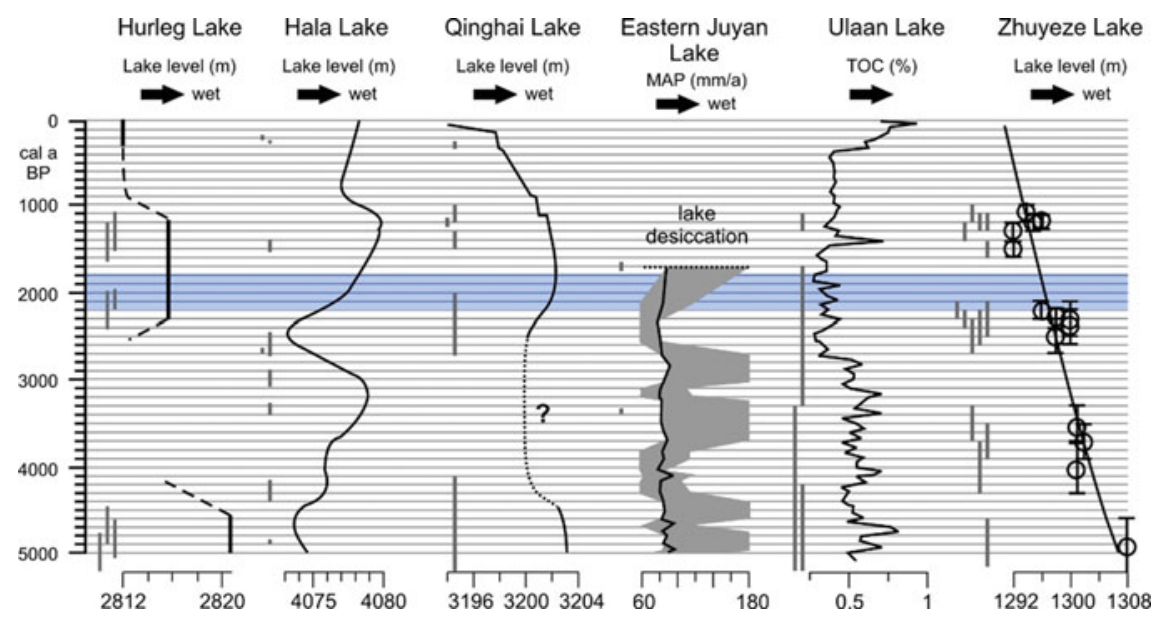

Fig. 3.4 Lake records from the eastern section of the discussed region. Vertical grey bars at left of records indicate age data with $2 \sigma$ error ranges. Duration of Han Dynasty marked by blue bar. (References and additional chronological information provided in Table 3.1) 
Han time. The western part of the former lake basin (Qingtu Lake) fell dry 2100 a $\mathrm{BP}$ at the section location QTL02 investigated by Mischke et al. (2016).

Ulaan Lake is a terminal lake $600 \mathrm{~km}$ to the north of Zhuyeze Lake. The lake is dry since the mid 1990s until it was fed by the Ongin River from the southeastern ranges of the Khangai Mountains in central Mongolia. Total organic carbon (TOC) contents of lake sediments of a Holocene core were used as proxy of summer monsoon precipitation and warmer and moister climate by Lee et al. (2013). Before, during and after the Han Dynasty, very low TOC values indicate dry conditions and predominantly accumulation of detrital particles in the lake (Fig. 3.4). Thus, generally dry conditions were recorded at Ulaan Lake during the Han Dynasty. However, the obtained OSL age data have large uncertainties and more studies are required to understand climate conditions in southern Mongolia during the last millennia (Fig. 3.4).

\subsubsection{Speleothem Records}

Two speleothem records are available for the region, the Uluu-Too Cave record from the western Tianshan Mountains and the Kesang Cave record from the eastern part of the mountain range. Relatively low $\delta^{18} \mathrm{O}$ values for the speleothem record from Uluu-Too Cave during the Han Dynasty suggest relatively wet conditions (Wolff et al. 2016; Fig. 3.5). Higher values 200 a before the beginning of the Han time and also soon afterwards indicate relatively dry conditions. The $\delta^{18} \mathrm{O}$ pattern is different at Kesang Cave $800 \mathrm{~km}$ further to the northeast. The $\delta^{18} \mathrm{O}$ values are moderate during the Han period with lower values indicating wetter conditions before and mostly higher values suggesting relatively dry conditions afterwards (Cheng et al. 2012; Fig. 3.5). Thus, the two speleothem records from the Tianshan Mountains do not provide a consistent reconstruction of the climate conditions in the region. The Uluu-Too Cave record shows some similarities with the $\delta \mathrm{D}$ record from Karakuli Lake which is $320 \mathrm{~km}$ to the southeast of the cave location. Low $\delta^{18} \mathrm{O}$ values of the cave carbonates and low $\delta \mathrm{D}$ values for terrestrial biomarkers from Karakuli Lake were recorded at 3000 a BP or shortly before, at 2500 a BP and at the end of the Han Dynasty 1800 a BP (Aichner et al. 2015; Wolff et al. 2016; Figs. 3.2 and 3.5). Similarities with the closer Karakul Lake in Tajikistan $(170 \mathrm{~km}$ in the southeast of Uluu-Too Cave) are less obvious. Sayram Lake is the closest lake record for Kesang Cave, but the wetness proxies from both sites show unrelated patterns apart from possibly corresponding wet conditions inferred from Kesang Cave 600 a BP and at Sayram Lake 800 a BP. There are significant altitudinal differences between the cave and lake locations, and it is not clear whether stable isotope or pollen records from lakes reflecting catchment-wide climate conditions or regional vegetation changes can be easily compared with more site-specific speleothem records. The $\delta^{18} \mathrm{O}$ records of the speleothems mainly reflect the stable isotope composition of precipitation above the caves which is mainly determined by $\delta^{18} \mathrm{O}$ changes of water vapour in upstream regions and the pathways of air masses. Air mass trajectories for UluuToo Cave in 2014 show a large variability of moisture source areas ranging from 


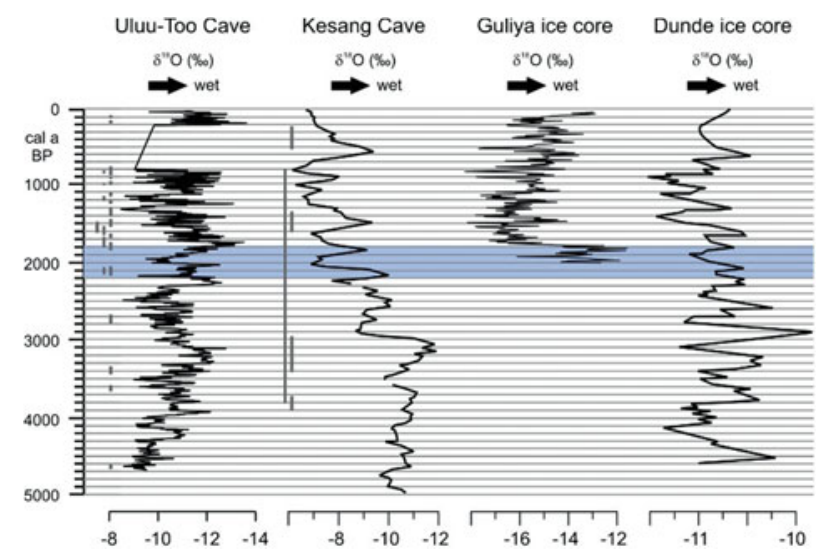

Fig. 3.5 Speleothem and ice core records from northwestern China. Vertical grey bars at left of cave records indicate U/Th ages with $2 \sigma$ error ranges. Duration of Han Dynasty marked by blue bar. (References and additional chronological information provided in Table 3.1)

the Atlantic Ocean off northwestern Africa to the Barents Sea in the Arctic Ocean (Wolff et al. 2016). Besides trajectories and moisture sources, seasonality changes and snow melt contribution were regarded as most significant factors controlling the $\delta^{18} \mathrm{O}$ signal of the Uluu-Too Cave record (Wolff et al. 2016). Snow melt might be partly controlled by local wind strength and direction. The Uluu-Too Cave region in the central Tianshan Mountains is dominated by winter and spring rainfall whilst Kesang Cave in the eastern part of the Tianshan Mountains and at $500 \mathrm{~m}$ higher altitude mainly receives spring-summer precipitation. Slight temperature changes in the past may have caused changes in precipitation seasonality. Thus, it remains open to which degree long-term changes of $\delta^{18} \mathrm{O}$ values at the caves reflect changes in precipitation amount or changes in dominating air mass trajectories and moisture source areas, seasonality or other factors.

\subsubsection{Ice Core Records}

Ice cores from the Guliya ice cap in the western Kunlun Mountains and the Dunde ice cap in the Qilian Mountains may provide additional evidence for climate conditions during the Han Dynasty. High resolution $\delta^{18} \mathrm{O}$ data for ice accumulated during the last 2000 a BP at Guliya were presented by Yang et al. (2004). The $\delta^{18} \mathrm{O}$ values are high during the second half of the Han Dynasty (2000-1800 a BP) and shift to significantly lower values afterwards (Fig. 3.5). Thus, warmer and wetter conditions during the Han time are indicated by the Guliya ice core data with an abrupt cooling and aridification after its termination. 
Comparison of the Guliya ice core data with lake records from the region is not straightforward due to its large distance to nearest lake records. The closest lake record was provided from Karakuli Lake which is located $670 \mathrm{~km}$ to the northwest of Guliya. Increasingly wet conditions were recorded at Karakuli Lake and also at Son Kol Lake during the Han Dynasty (Lauterbach et al. 2014; Aichner et al. 2015; Fig. 3.2). In contrast to the abrupt shift to drier conditions after the termination of the Han observed at Guliya, gradual and long-term transitions to drier conditions were recorded at the two lakes (Yang et al. 2004). The reconstruction of wetter conditions in the centuries after the Han Dynasty at Sasikul, Karakul, Balkhash and Issyk-Kul lakes is contrary to the inference of drier climate conditions from Guliya (Ricketts et al. 2001; Mischke et al. 2010; Sugai 2012; Lei et al. 2014; Fig. 3.2). However, distances between these regions are large and spatial differences in climate conditions are possibly reflected at the individual locations.

The $\delta^{18} \mathrm{O}$ data from Dunde ice cap are relatively moderate and less variable during the Han Dynasty in comparison to the preceding 2400 a and the subsequent 1800 a BP (Yao and Thompson 1992; Fig. 3.5). Relatively moderate and stable climate conditions are suggested by the Dunde ice core record. The Dunde ice cap is located $100 \mathrm{~km}$ to the west of Hala Lake and $100 \mathrm{~km}$ in the north of Hurleg Lake (Fig. 3.1). Moderate and increasingly wet conditions inferred from Hala Lake possibly correspond to the moderate $\delta^{18} \mathrm{O}$ values from the Dunde ice core record. Similarities in both records are also the inference of relatively wet conditions 2900 a BP and during the most recent centuries, and of relatively dry climate 4100 and 900 a BP (Figs. 3.4 and 3.5). Similarities exist also between the Dunde ice core and the Hurleg Lake records: relatively wet conditions are inferred at 4500 a BP, during the Han Dynasty and in the most recent centuries, and relatively dry conditions 4100 and 900 a BP. However, the temporal resolution of the shoreline age data from Hurleg Lake does not allow a detailed comparison with the $\delta^{18} \mathrm{O}$ data from Dunde. Moderate and wetter conditions at the Dunde ice cap 4500 a BP and during the Han Dynasty apparently correspond to higher lake levels at Qinghai Lake $350 \mathrm{~km}$ to the southeast of the ice cap. In contrast, the inferred period of low lake levels at Qinghai Lake (4500-2500 a $\mathrm{BP})$ does not correspond to relatively high $\delta^{18} \mathrm{O}$ values of the Dunde ice cap record.

Inconsistencies between ice core and lake records may not only arise from spatial heterogeneities of climate conditions but also from dating uncertainties of OSL ages for shoreline deposits, and poorly constrained chronologies of ice core data (missing annual layers due to removal of snow by wind or ablation, multiple dust layers in years with several severe storms or missing dust layers in less stormy years). In addition, lake records may not only reflect climate conditions but also local human impact in contrast to ice core records. For example, wetter conditions inferred for the most recent centuries at Dunde were also inferred at Hala Lake and Hurleg Lake. The lake-level fall at Qinghai Lake during most recent centuries corresponds not to the inferences from Dunde ice core and Hala and Hurleg lakes, and possibly results from water withdrawal from the lake's tributaries for farming purposes (Fig. 3.4). 


\subsection{Lake Records Which Indicate Significant Drying During or After the Han Dynasty}

The majority of the lake records indicate either increasing moisture availability during the Han Dynasty (Balkhash, Karakuli, Son Kol, Issyk-Kul, Sayram, Aibi, Manas, Balikun and Hala lakes) or generally wet conditions (Wulungu, Hurleg and Qinghai lakes; Figs. 3.2, 3.3 and 4). A significant decrease of moisture available and drier conditions during the Han period or shortly afterwards were recorded at Bosten, Lop Nur, Eastern Juyan and Zhuyeze lakes (Figs. 3.3 and 3.4). Generally dry conditions during the Han time and in the centuries before and afterwards were recorded at three lakes (Sasikul, Karakul and Ulaan lakes; Figs. 3.2 and 3.4).

Different types of evidence were provided for the four lakes which apparently experienced distinctive reductions in moisture availability during the Han time or in the subsequent centuries. The desiccation of the Eastern Juyan Lake at 1700 a BP is probably the most significant evidence for dramatic landscape change (Herzschuh et al. 2004). However, the record of predominantly aeolian sands in the Lop Nur Lake region at 1800 a BP for the first time since sediments were accumulated in the investigated sequence at 9000 a BP is also strong evidence for a significant decrease in moisture availability and the near desiccation of the lake (Mischke et al. 2017). $\delta^{18} \mathrm{O}$ values of lake carbonates increased by $4 \%$ at Bosten Lake between 2300 and 2100 a BP, and a major reduction in moisture availability and inflow was reconstructed (Zhang et al. 2010). Shoreline deposits higher before the Han Dynasty and ca. $4 \mathrm{~m}$ lower afterwards were recorded at Zhuyeze Lake (Long et al. 2012). Thus, the accumulated evidence for drier conditions at these lakes during the Han time and shortly afterwards is robust.

The four lakes are all located in the forelands of high mountain ranges. The catchment areas are generally large, ranging from $>500,000 \mathrm{~km}^{2}$ for Lop Nur Lake to $41,600 \mathrm{~km}^{2}$ for Zhuyeze Lake (Long et al. 2012). Thus, the four lakes represent relatively large regions and do not reflect local hydrological peculiarities. Tributaries of the four lakes originate at high altitude in the Tianshan and Qilian Mountains. The main tributaries of Bosten and Lop Nur Lake are the Kaidu, Konqi and Tarim rivers which flow through the transitional belts between the mountains and the deserts in the basin centres which are mostly used for agriculture today. Similarly, most of today's intensively farmed fertile Hexi Corridor in the northern foreland of the Qilian Mountains is drained by the tributaries of the Eastern Juyan (Hei River) and Zhuyeze (Shiyang River) lakes. Thus, all four lakes are characterized by catchment areas which include significant portions along the foot of large mountain ranges intensively used as farmlands today. Another characteristic in common with the lakes that experienced a change to significantly drier conditions during the Han Dynasty or in the following centuries is that these lakes are situated within the area of the Han Dynasty expansion of the Chinese empire (Fig. 3.6). All other examined lake records originate from regions in the west, north or south of the Han Dynasty realm.

The spatial pattern of a change to significantly drier conditions during or shortly after the Han Dynasty at the four lakes and mostly increasingly wetter or generally 


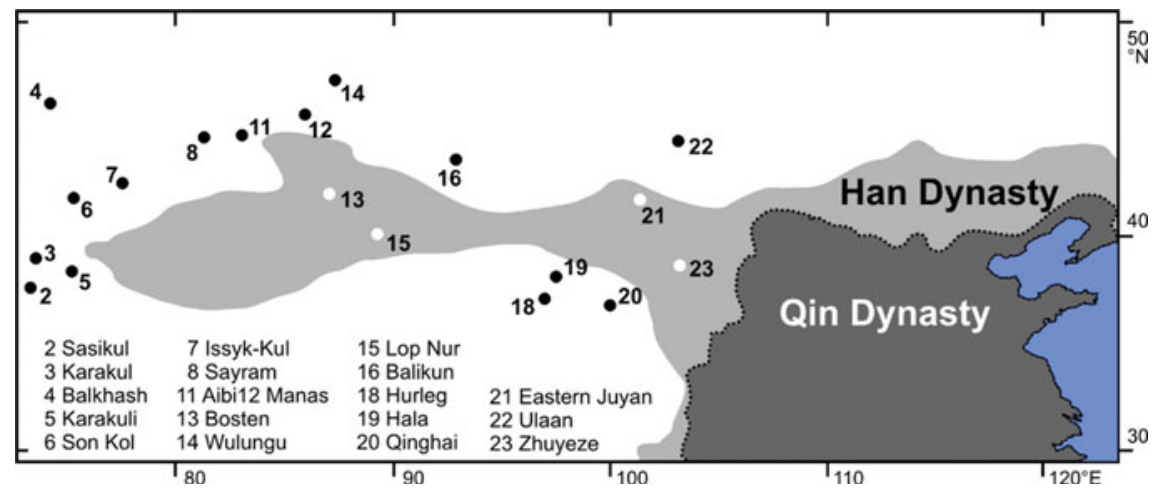

Fig. 3.6 Lake records from northwestern China and surrounding regions which experienced a significant decline in water level during or shortly after the Han Dynasty (white dots) or relatively stable or relatively wet conditions (black dots). (References provided in Table 3.1)

relatively wet conditions in adjacent regions of the Han empire cannot be explained by regional climate change. Instead, the coincidence of (1) lake basins situated within the expansion realm of the Chinese empire, (2) large catchment areas with significant portions in regions along the foot of mountain ranges appropriate for irrigation farming, and (3) recorded decreases of moisture availability during the Han time or in subsequent centuries, suggests that the water balance of these lakes was affected by human activities. Appropriate regions for irrigation farming are located in the middle reaches of the catchment areas of these lakes, and are used for intensive irrigation farming today. Thus, water withdrawal from the tributaries of the four lakes must have caused the desiccation of the Eastern Juyan Lake, the near desiccation of Lop Nur Lake, the lake-level drop of Zhuyeze Lake and reduction in inflow of Bosten Lake. Yang et al. (2006) compiled historical data for the oases agriculture in the Tarim and Yanqi basins in the Han and Qing (17-20th centuries) dynasties and concluded that the area of cultivated land was significantly larger during the Han Dynasty. They argued that land-use practices and climate change caused the transformation of the large Lop Nur Lake in the Han Dynasty to a group of small lakes in the Qing Dynasty. However, they also claimed that "It is somehow unlikely that the irrigated area [in the Korla region, northeastern Tarim Basin; information added] at that time [i.e., during the Han time; information added] was larger than at present." More geological, geomorphological and archaeological research is required to better understand human impact on the landscape during the Han Dynasty.

However, resulting landscape change in and near the lake regions must have been dramatic due to the flat topography of the lake basins in mountain foreland regions and the large areas affected. Several ten thousands of square kilometres of open water surface were probably turned into barren desert or salt marshes due to human activities already ca. 2000 a BP. The former area of Lop Nur Lake is estimated as 17,000 to $50,000 \mathrm{~km}^{2}$ of which most was probably dry during the near-desiccation state 1800 a BP (Yang et al. 2006). Eastern Juyan Lake may have covered $320 \mathrm{~km}^{2}$ 
before its desiccation (Hartmann et al. 2011). The drying of the western sub-basin of Zhuyeze Lake, the Qingtu Lake Basin, probably left some $500 \mathrm{~km}^{2}$ of previous lake area dry. The areal changes of Bosten Lake are not inferred in a straightforward way from the stable isotope data but the observed $1.5 \mathrm{~m}$ lake-level difference between the years 1980 and 2000 caused a change of lake area by ca. $650 \mathrm{~km}^{2}$, which shows that a relatively minor lake level fall results in a significant lake area reduction (Wang et al. 2003). Thus, substantial areas were apparently turned into barren desert or salt marshes in the four lake regions as a consequence of water withdrawal from tributaries during the Han Dynasty and in the subsequent centuries.

Whilst regional changes of climate conditions are ruled out here as potential drivers of lake desiccation or lake-level decrease during and after the Han time, hydrological changes may have contributed to the desiccation of the Eastern Juyan Lake. Active channels of the Hei River on its large alluvial fan in the north of the Hexi Corridor may have become inactive due to the rapid filling of channels by fluvial sediments and formation of new channels, or due to blockage of active channels by dunes moving over the fan surface. Thus, the terminal Eastern Juyan Lake on the distal margin of the fan is not only controlled by regional climate conditions and discharge under natural conditions, and by water withdrawal upstream in the Hexi Corridor, but also by channel avulsion processes in a flat-lying terrain. However, similar processes were probably negligible for the other three lake catchments.

Another yet ignored line of evidence for potential landscape change triggered by man during the Han Dynasty or in subsequent centuries is the change of land-use practices and possible landscape degradation in or near the core region of the Chinese empire. For example, dramatic landscape change ca. 2000 a BP has been reported from the Ulan Buh Desert in southwestern Inner Mongolia at the margin of the Qin Dynasty realm preceding the Han Dynasty (Li et al. 2015). Tectonic activity and climate change were suggested as causes of aridification in the Ulan Buh Desert so far ( $\mathrm{Li}$ et al. 2015). Further to the east and within the Qin Dynasty realm, sand mobilization and dune formation occurred apparently already as a result of a massive migration of people and farming intensification in the Mu Us Desert region during the earlier half of the Han time, the Western Han (206 BCE-9 CE; Sun 2000). Here, man's impact was clearly identified. Further in the southeastern part of the Mu Us Desert, studies by Li et al. (2011) and Liu and Lai (2012) implied a drastic change from long-term sediment accumulation to rapid incision of the Salawusu River by $60 \mathrm{~m}$ since 2000 or 1750 a BP. Other rivers on the Chinese Loess Plateau have late Pleistocene and older terraces, and apparently significantly lower erosion rates (Qiu et al. 2014). Thus, it remains open to which degree intensified land use or changing practices during the prosperous Han Dynasty may have contributed to landscape change in the core region of the Chinese Empire too. 


\subsection{Conclusions and Perspectives}

The comparison of lake, speleothem and ice core records from northwestern China and surrounding regions for the Han Dynasty period and subsequent centuries shows that relatively wet climate conditions were mostly inferred for areas immediately to the west, north and south of the Han Empire realm. In contrast, the available four lake records from within the Han Empire region witnessed decreased moisture availability and significant landscape change ranging from substantial decreases in lake level and open-water surface areas (Bosten and Zhuyeze lakes) to near (Lop Nur Lake) or complete desiccation (Eastern Juyan Lake) of lake basins. The spatial pattern of lake records indicating drier conditions during the Han time or shortly afterwards cannot be explained by climate change due to mostly wetter conditions inferred from nearby locations which are outside the Han Dynasty region. Thus, man-made impact on surface waters must already have reached an order of magnitude during the Han Dynasty which was sufficient to cause large-scale landscape change. Water withdrawal from the tributaries of the lakes for irrigation farming was most likely the main driver of landscape deterioration downstream.

The timing of landscape response is not very consistent and partly not well constrained for the four lake basins. Significant reductions in inflow are recorded at Bosten and Lop Nur lakes as early as 2300 a BP and more significantly at Lop Nur Lake 1800 a BP whilst the desiccation of the Eastern Juyan Lake occurred 1700 a BP. The underlying radiocarbon and OSL chronologies are likely not precise due to problematic materials used for dating (e.g., bulk organic matter for radiocarbon dating potentially biased by lake-reservoir effects; Mischke et al. 2013) or uncertainties in post-depositional water content assessments for OSL dating. The lowering of the level of Zhuyeze Lake during the Han Dynasty is also not precisely constrained due to the dating of higher shoreline deposits with ages preceding the Han time and dating of lower deposits formed after the Han Dynasty (Fig. 3.4). Thus, it remains open whether man exerted significant impacts on local hydrological systems already as early as the beginning of the Han Dynasty or even before, or whether significant impacts occurred only after the initial Han Dynasty expansion to the west. Better constrained chronological control is required to answer such questions in the future.

Our conclusion that man impacted the landscape already in a very significant way as early as the Han Dynasty clearly calls for an assessment using other lines of evidence. Archaeological field evidence for intensive irrigation farming during the Han Dynasty such as remnants of artificial channels, dams and reservoirs, soils and farmlands buried beneath aeolian sands, and ruins of desert oases from Han times could be assessed in future studies in addition to the screening of written historical documents. Detailed geological, geomorphological and archaeological studies are required to better understand early human impact on fragile landscapes in the arid and semi-arid regions of Central Asia.

Acknowledgements Funding was provided by China's NSF projects (40830420, 41471003), the State key project (2003BA612A-06-15) of the Ministry of Science and Technology of China and the German Research Foundation (DFG grant Mi 730/16-1). PAGES provided a travel grant to SM 
for participation in the workshop "The Rise and Fall: Environmental Factors in the Socio-Cultural Changes of the Ancient Silk Road Area" in Kiel (Germany) in September 28-29, 2017.

\section{References}

Aichner, B., Feakins, S., Lee, J. E., Herzschuh, U., \& Liu, X. (2015). High-resolution leaf wax carbon and hydrogen isotopic record of the late Holocene paleoclimate in arid Central Asia. Climate of the Past, 11, 619-633.

Akhmetyev, M. A., Dodoniv, A. E., Somikova, M. V., Spasskaya, I. I., Kremenetsky, K. V., \& Klimanov, V. A. (2005) Kazakhstan and Central Asia (Plains and foothills). In A. A. Velichko, \& V. P. Nechaev (Eds.), Cenozoic climatic and environmental changes in Russia (vol. 382, pp. 139-161). Geological Society of America Special Paper.

An, Z., Porter, S. C., Kutzbach, J. E., Wu, X., Wang, S., Liu, X., et al. (2000). Asynchronous Holocene optimum of the East Asian monsoon. Quaternary Science Reviews, 19, 743-762.

Chen, F., Yu, Z., Yang, M., Ito, E., Wang, S., Madsen, D. B., et al. (2008). Holocene moisture evolution in arid central Asia and its out-of-phase relationship with Asian monsoon history. Quaternary Science Reviews, 27, 351-364.

Cheng, H., Zhang, P. Z., Spötl, C., Edwards, R. L., Cai, Y. J., Zhang, D. Z., et al. (2012). The climatic cyclicity in semiarid-arid central Asia over the past 500,000 years. Geophysical Research Letters, 39, L01705. https://doi.org/10.1029/2011GL050202.

Chen, F., Wu, D., Chen, J., Zhou, A., Yu, J., Shen, J., et al. (2016). Holocene moisture and East Asian summer monsoon evolution in the northeastern Tibetan Plateau recorded by Lake Qinghai and its environs: A review of conflicting proxies. Quaternary Science Reviews, 154, 111-129.

Chiba, T., Endo, K., Sugai, T., Haraguchi, T., Kondo, R., \& Kubota, J. (2016). Reconstruction of Lake Balkhash levels and precipitation/evaporation changes during the last 2000 years from fossil diatom assemblages. Quaternary International, 397, 330-341.

Endo, K., Chiba, T., Sugai, T., Haraguchi, T., Yamazaki, H., Nakayama, H., Yoshinaga, Y., Miyata, K., Ogino, O., Arakawa, K., Nakao, Y., Komori, J., Kondo, Matsuoka, H., Aubekerov, B. Z., Sala, R., Deom, J.-M., Sohma, R., \& Kubota, J. (2010). Reconstruction of lake level and paleoenvironmental changes from a core from Balkhash Lake, Kazakhstan. In M. Watanabe, \& J. Kubota (Eds.), Reconceptualizing cultural and environmental change in Central Asia: An historical perspective on the future (pp. 93-104).

Fan, Q. S., Ma, H. Z., Wei, H. C., \& An, F. Y. (2014). Holocene lake-level changes of Hurleg Lake on northeastern Qinghai-Tibetan Plateau and possible forcing mechanism. The Holocene, 24, 274-283.

Hartmann, K., Wünnemann, B., Hölz, S., Kraetschell, A., \& Zhang, H. C. (2011). Neotectonic constraints on Gaxun Nur inland basin in north-central China, derived from remote sensing, geomorphology and geophysical analyses. In R. Gloaguen, \& L. Ratschbacher (Eds.), Growth and collapse of the Tibetan Plateau (vol. 353, pp. 221-233). Geological Society London Special Publications.

Herzschuh, U., Tarasov, P., Wünnemann, B., \& Hartmann, K. (2004). Holocene vegetation and climate of the Alashan Plateau, NW China, reconstructed from pollen data. Palaeogeography, Palaeoclimatology, Palaeoecology, 211, 1-17.

Jiang, Q. F., Ji, J. F., Shen, J., Matsumoto, R., Tong, G. B., Qian, P., et al. (2013). Holocene vegetational and climatic variation in westerly dominated areas of Central Asia inferred from the Sayram Lake in northern Xinjiang, China. Science in China Earth Sciences, 56, 339-353.

Jin, X., Liu, H., Tu, Q., Zhang, Z., \& Zhu, X. (Eds.). (1990). Eutrophication of lakes in China. In The fourth international conference on the conservation and management of lakes, Hangzhou '90 (652 pp). Chinese Research Academy of Environmental Sciences. 
Lauterbach, S., Witt, R., Plessen, B., Dulski, P., Prasad, S., Mingram, J., et al. (2014). Climatic imprint of the mid-latitude westerlies in the central Tian Shan of Kyrgyzstan and teleconnections to North Atlantic climate variability during the last 6000 years. The Holocene, 24, 970-984.

Lee, M. K., Lee, Y. I., Lim, H. S., Lee, J. I., \& Yoon, H. I. (2013). Late Pleistocene-Holocene records from Lake Ulaan, southern Mongolia: Implications for east Asian palaeomonsoonal climate changes. Journal of Quaternary Science, 28, 370-378.

Lei, Y., Tian, L., Bird, B. W., Hou, J., Ding, L., Oimahmadov, I., et al. (2014). A 2540-year record of moisture variations derived from lacustrine sediment (Sasikul Lake) on the Pamir Plateau. The Holocene, 24, 761-770.

Li, S.-H., Sun, J., \& Li, B. (2011). Holocene environmental changes in central Inner Mongolia revealed by luminescence dating of sediments from the Sala Us River valley. The Holocene, 22, 397-404.

Li, G., Jin, M., Chen, X., Wen, L., Zhang, J., Madsen, D., et al. (2015). Environmental changes in the Ulan Buh Desert, southern Inner Mongolia, China since the middle Pleistocene based on sedimentology, chronology and proxy indexes. Quaternary Science Reviews, 128, 69-80.

Liu, K., \& Lai, Z. (2012). Chronology of Holocene sediments from the archaeological Salawusu site in the Mu Us Desert in China and its palaeoenvironmental implications. Journal of Asian Earth Sciences, 45, 247-255.

Liu, X., Herzschuh, U., Shen, J., Jiang, Q., \& Xiao, X. (2008). Holocene environmental and climatic changes inferred from Wulungu Lake in northern Xinjiang, China. Quaternary Research, 70 , $412-425$.

Liu, J., Chen, J., Zhang, X., Li, Y., Rao, Z., \& Chen, F. (2015a). Holocene East Asian summer monsoon records in northern China and their inconsistency with Chinese stalagmite $\delta 18 \mathrm{O}$ records. Earth-Science Reviews, 148, 194-208.

Liu, X. J., Lai, Z., Madsen, D., \& Zeng, F. (2015b). Last deglacial and Holocene lake level variations of Qinghai Lake, north-eastern Qinghai-Tibetan Plateau. Journal of Quaternary Science, 30, 245-257.

Long, H., Lai, Z., Fuchs, M., Zhang, J., \& Li, Y. (2012). Timing of Late Quaternary palaeolake evolution in Tengger Desert of northern China and its possible forcing mechanisms. Global and Planetary Change, 92-93, 119-129.

Lü, H., Xia, X., Liu, J., Qin, X., Wang, F., Yidilisi, A., et al. (2009). A preliminary study of chronology for a newly discovered ancient city and five archaeological sites in Lop Nor, China. Chinese Science Bulletin, 55, 63-71.

Mischke, S., \& Wünnemann, B. (2006). The Holocene salinity history of Bosten Lake (Xinjiang, China) inferred from ostracod species assemblages and shell chemistry: Possible palaeoclimatic implications. Quaternary International, 154-155, 100-112.

Mischke, S., Rajabov, I., Mustaeva, N., Zhang, C., Herzschuh, U., Boomer, I., et al. (2010). Modern hydrology and late Holocene history of Lake Karakul, eastern Pamirs (Tajikistan): A reconnaissance study. Palaeogeography, Palaeoclimatology, Palaeoecology, 289, 10-24.

Mischke, S., Weynell, M., Zhang, C., \& Wiechert, U. (2013). Spatial variability of ${ }^{14} \mathrm{C}$ reservoir effects in Tibetan Plateau lakes. Quaternary International, 313-314, 147-155.

Mischke, S., Lai, Z., Long, H., \& Tian, F. (2016). Holocene climate and landscape change in the northeastern Tibetan Plateau foreland inferred from the Zhuyeze Lake record. The Holocene, 26, 643-654.

Mischke, S., Liu, C., Zhang, J., Zhang, C., Zhang, H., Jiao, P., et al. (2017). The world's earliest Aral-Sea type disaster: the decline of the Loulan Kingdom in the Tarim Basin. Scientific Reports, 7, 43102.

Narama, C., Kicengge, Kubota, J., Shatravin, V., Duishonakunov, M., Moholdt, G., \& Abdrakhmatov, K. (2010). The lake-level changes in Central Asia during the last 1000 years based on historical map. In M. Watanabe, \& J. Kubota (Eds.), Reconceptualizing cultural and environmental change in Central Asia: An historical perspective on the future (pp. 11-27). 
Qin, X., Liu, J., Jia, H., Lu, H., Xia, X., Zhou, L., et al. (2012). New evidence of agricultural activity and environmental change associated with the ancient Loulan kingdom, China, around 1500 years ago. The Holocene, 22, 53-61.

Qiu, W.-L., Zhang, J.-F., Wang, X.-Y., Guo, Y.-J., Zhuang, M.-G., Fu, X., et al. (2014). The evolution of the Shiwanghe River valley in response to the Yellow River incision in the Hukou area, Shaanxi, China. Geomorphology, 215, 34-44.

Rhodes, T. E., Gasse, F., Lin, R., Fontes, J.-C., Wei, K., Bertrand, P., et al. (1996). A Late PleistoceneHolocene lacustrine record from Lake Manas, Zunggar (northern Xinjiang, western China). Palaeogeography, Palaeoclimatology, Palaeoecology, 120, 105-121.

Ricketts, R. D., Johnson, T. C., Brown, E. T., Rasmussen, K. A., \& Romanovsky, V. V. (2001). The Holocene paleolimnology of Lake Issyk-Kul, Kyrgyzstan: Trace element and stable isotope composition of ostracodes. Palaeogeography, Palaeoclimatology, Palaeoecology, 176, 207-227.

Savvaitova, K., \& Petr, T. (1992). Lake Issyk-kul, Kirgizia. International Journal of Salt Lake Research, 1, 21-46.

Sugai, T. (2012). Holocene climatic changes of the Balkhash Lake region, Kazakhstan, reconstructed from high-resolution XRF scanning analyses of the lake sediments coupled with geomorphic investigations of the catchment area. Quaternary International, 279-280, 475.

Sun, J. (2000). Origin of eolian sand mobilization during the past 2300 years in the Mu Us Desert, China. Quaternary Research, 53, 78-88.

Tao, S. C., An, C. B., Chen, F. H., Tang, L. Y., Wang, Z. L., Lü, Y. B., et al. (2010). Pollen-inferred vegetation and environmental changes since $16.7 \mathrm{ka}$ BP at Balikun Lake. Xinjiang. Chinese Science Bulletin, 55, 2449-2457.

Wang, R., Giese, E., \& Gao, Q. (2003). Seespiegelschwankungen des Bosten-Sees (VR China). Zentrum für internationale Entwicklungs- und Umweltforschung (ZEU) der Justus-Liebig-Universität Gießen. Diskussionsbeiträge, 13, 1-38.

Wang, Y., Liu, X., \& Herzschuh, U. (2010). Asynchronous evolution of the Indian and East Asian summer monsoon indicated by Holocene moisture patterns in monsoonal central Asia. EarthScience Reviews, 103, 135-153.

Wang, W., Feng, Z., Ran, M., \& Zhang, C. (2013). Holocene climate and vegetation changes inferred from pollen records of Lake Aibi, northern Xinjiang, China: A potential contribution to understanding of Holocene climate pattern in East-central Asia. Quaternary International, 311, $54-62$.

Wolff, C., Plessen, B., Dudashvilli, A. S., Breitenbach, S. F. M., Cheng, H., Edwards, L. R., et al. (2016). Precipitation evolution of Central Asia during the last 5000 years. The Holocene, 27, $142-154$.

Wünnemann, B., Wagner, J., Zhang, Y., Yan, D., Wang, R., Shen, Y., et al. (2012). Implications of diverse sedimentation patterns in Hala Lake, Qinghai Province, China for reconstructing late quaternary climate. Journal of Paleolimnology, 48, 725-749.

Yang, X., \& Liu, X. (2014). Drastic change in China's lakes and reservoirs over the past decades. Scientific Reports, 4, 6041.

Yang, B., Braeuning, A., Shi, Y., \& Chen, F. (2004). Evidence for a late Holocene warm and humid climate period and environmental characteristics in the arid zones of northwest China during $2.2 \sim 1.8$ kyr B.P. Journal of Geophysical Research, 109, D02105.

Yang, X., Liu, Z., Zhang, F., White, P. D., \& Wang, X. (2006). Hydrological changes and land degradation in the southern and eastern Tarim Basin, Xinjiang, China. Land Degradation and Development, 17, 381-392.

Yao, T., \& Thompson, L. G. (1992). Trends and features of climatic changes in the past 5000 years recorded by the Dunde ice core. Annals of Glaciology, 16, 21-24.

Zhang, H., Wu, J. W., Zheng, Q. H., \& Yu, Y. J. (2003). A preliminary study of oasis evolution in the Tarim basin, Xinjiang, China. Journal of Arid Environments, 55, 545-553.

Zhang, C., Feng, Z., Yang, Q., Gou, X., \& Sun, F. (2010). Holocene environmental variations recorded by organic-related and carbonate-related proxies of the lacustrine sediments from Bosten Lake, northwestern China. The Holocene, 20, 363-373. 
Zhang, F., Wang, T., Yimit, H., Shi, Q., Ruan, Q., Sun, Z., et al. (2011). Hydrological changes and settlement migrations in the Keriya River delta in central Tarim Basin ca. 2.7-1.6 ka BP: Inferred from ${ }^{14} \mathrm{C}$ and OSL chronology. Science China Earth Sciences, 54, 1971-1980.

Zheng, Z., Yuan, B., \& Petit-Maire, N. (1998). Paleoenvironments in China during the last glacial maximum and the Holocene optimum. Episodes, 21, 152-158.

Zhou, X., Zhu, F., \& Li, S. (1994). The formation and evolution of oasis in the Keriya River valley. Quaternary Sciences, 3, 249-255.

Open Access This chapter is licensed under the terms of the Creative Commons Attribution 4.0 International License (http://creativecommons.org/licenses/by/4.0/), which permits use, sharing, adaptation, distribution and reproduction in any medium or format, as long as you give appropriate credit to the original author(s) and the source, provide a link to the Creative Commons license and indicate if changes were made.

The images or other third party material in this chapter are included in the chapter's Creative Commons license, unless indicated otherwise in a credit line to the material. If material is not included in the chapter's Creative Commons license and your intended use is not permitted by statutory regulation or exceeds the permitted use, you will need to obtain permission directly from the copyright holder. 